\title{
ANALISIS KINERJA KEUANGAN PT SUMMARECON AGUNG TBK DAN PT PAKUWON JATI DENGAN MENGGUNAKAN METODE DU PONT SYSTEM DAN ANALISIS ECONOMIC VALUE ADDED (EVA) PERIODE 2015-2017
}

\author{
Esterlina Angela Juliana \\ Program Studi Magister Manajemen Universitas Tarumanagara \\ sthertuhumury@gmail.com
}

\begin{abstract}
Absctact : Research at PT Summarecon Agung Tbk and PT Pakuwon Jati Tbk, located in Jakarta, aims to assess the financial performance of PT Summarecon Agung Tbk and PT Pakuwon Jati Tbk 2015-2017. The analytical method uses in this research is Du Pont System and Economic Value Added (EVA). Du Pont System is an analysis system intended to show relation between return on investment, net profit margin, and total asset turnover. Economic Value Added (EVA) is an additional value to shareholders by management in a certain period. The result of the calculation of the financial performance of PT Summarecon Agung Tbk year period 2015-2017 with the Du Pont System shows a positive value and tend to increase per year. And for the analysis method of Economic Value Added shows value fluctuation also decrease per year. As for the analysis using the EVA method, the fluctuating value also decreases per year. The results of the calculation of the performance of PT Pakuwon Jati Tbk period in 2015-2017 with Du Pont System showed a positive value and experienced an increase and decrease every year. As for the analysis using the EVA method, the value of fluctuations also decrease and increase every year. In this case, the company needs to improve the efficiency of the company, both PT Summarecon Agung Tbk and PT Pakuwon Jati in utilizing capital and managing assets owned by the company.
\end{abstract}

Abstrak :Penelitian pada PT Summarecon Agung Tbk dan PT Pakuwon Jati Tbk yang berlokasi di Jakarta ini bertujuan untuk menilai kinerja keuangan PT Summarecon Agung Tbk dan PT Pakuwon Jati Tbk untuk periode 2015-2017. Metode analisis yang digunakan dalam penelitian ini adalah metode analisis Du Pont System dan metode analisis Economic Value Added (EVA). Du Pont System adalah suatu sistem analisis yang dimaksudkan untuk menunjukkan hubungan antara return on investment, net profit margin, dan total asset turnover. Economic Value Added (EVA) adalah nilai tambah kepada pemegang saham oleh manajemen dalam suatu periode tertentu. Hasil perhitungan kinerja keuangan PT Summarecon Agung Tbk periode tahun 2015-2017 dengan Du Pont System menunjukkan nilai yang positif namun cenderung mengalami penurunan setiap tahunnya. Sedangkan untuk analisis dengan metode EVA, menunjukkan nilai yang fluktuasi juga menurun per tahunnya. Hasil perhitungan kinerja PT Pakuwon Jati Tbk periode tahun 2015-2017 dengan Du Pont System menunjukkan nilai yang positif dan mengalami kenaikan sekaligus penurunan setiap tahunnya. Sedangkan untuk analisis dengan metode EVA, menunjukkan nilai yang mengalami fluktuasi penurunan juga kenaikan setiap tahunnya. Dalam hal ini, perusahaan perlu untuk meningkatkan efisiensi dari perusahaan baik itu PT Summarecon Agung Tbk maupun PT Pakuwon Jati dalam pendayagunaan modal maupun mengelola asset yang dimiliki perusahaan.

Keywords : Du Pont System, Economic Value Added (EVA), financial performances. 


\section{PENDAHULUAN}

Dunia investasi menjadi topik pembahasan menarik di era globalisasi seperti ini. Investasi sudah menjadi bagian fundamental ekonomi tidak hanya di negara maju, bahkan juga negara berkembang. Investasi pada hakikatnya merupakan penempatan sejumlah dana dengan harapan memperoleh keuntungan di masa mendatang. Investasi dapat dilakukan melalui sektor riil dan sektor keuangan (Novianingtiyas, 2013). Investasi sektor riil merupakan investasi yang berwujud fisik seperti tanah, bangunan, dan lain-lain. Sedangkan investasi sektor keuangan adalah saham dan obligasi.

Banyak masyarakat menginvestasikan modalnya di industri properti dikarenakan harga tanah yang cenderung naik. Penyebabnya adalah supply tanah bersifat tetap sedangkan demand akan selalu besar seiring pertumbuhan penduduk. Kenaikan yang terjadi pada harga tanah diperkirakan $40 \%$. Selain itu, harga tanah bersifat rigid, artinya penentu harga bukanlah pasar tetapi orang yang menguasai tanah (Rachbini, 1997).

Di Indonesia saat ini terdapat berbagai perusahaan yang menilik sektor properti dengan kompetisi yang tinggi yang mana perusahaan-perusahaan tersebut berusaha merancang untuk memenuhi kebutuhan konsumen. Tahun 2015 lalu telah menandai kehadiran PT Summarecon Agung Tbk (SMRA) selama lebih dari 40 tahun berkiprah dalam industri properti di Indonesia, sejak perusahaan didirikan pada tahun 1957. Pesaing terdekat dalam industri yang sama adalah PT Pakuwon Jati Tbk (PWON).

PT Summarecon Agung Tbk (SMRA) dan PT Pakuwon Jati (PWON) adalah perusahaan terbuka pada sektor properti yang sudah tidak asing lagi bagi masyarakat Indonesia. SMRA memiliki total asset sebesar Rp. 21.662 (dalam miliyar) pada tahun 2017, sedangkan PWON memilik total asset sebesar Rp. 23.358 (dalam milyar) untuk tahun yang sama. Kedua perusahaan juga membukukan laba bersih yang terus meningkat setiap tahunnya. Dengan perbedaan nilai total asset yang cukup besar dan laba bersih yang terus meningkat.

Mereka yang memiliki kepentingan terhadap perkembangan suatu perusahaan sangatlah perlu untuk mengetahui kinerja perusahaan tersebut. Untuk melihat kinerja perusahaan dimaksud terhadap pesaing diperlukan analisis keuangan perusahaan yang bersangkutan. Laporan keuangan tersebut berisi informasi keuangan suatu perusahaan yang terdiri dari neraca (balanced sheet), laporan laba rugi, laporan perubahan posisi keuangan, dan laporan pelengkap lainnya.

\section{TUJUAN PENELITIAN}

Tujuan penelitian ini adalah untuk penilaian kinerja perusahaan subsektor properti dilakukan dengan metode Du Pont Analysis. Metode Du Pont merupakan suatu analisis yang dilakukan secara bertahap dengan tolak ukur earning pada perusahaan, hasil akhir Du Pont analisis adalah Return On Equity dan Return On Asset. Dengan Du Pont analisis ini, pihak manajemen maupun investor akan dapat mengetahui faktor-faktor penyebab yang mempengaruhi tinggi rendahnya Return On Equity dan Return On Assets suatu perusahaan. Tolak ukur lain yang dapat digunakan oleh perusahaan yang memiliki peranan dalam meningkatkan nilai adalah metode Economic Value Added (EVA). EVA mengukur perbedaan pengembalian atas modal perusahaan dan biaya modal. Atau dengan kata lain dapat digunakan untuk mengukur nilai tambah yang dihasilkan perusahaan kepada investor. 


\section{TINJAUAN PUSTAKA}

\section{Laporan Keuangan}

Laporan keuangan pada dasarnya merupakan produk akhir dan serangkaian proses pencatatan dan pengikhtisaran data bisnis, juga merupakan gambaran kondisi keuangan yang telah dicapai perusahaan pada periode tertentu. Munawir dalam Sutardi (2007) memberikan pengertian bahwa laporan keuangan pada umumnya terdiri dari neraca dan perhitungan rugi laba serta laporan perubahan modal, di mana neraca menunjukkan jumlah aktiva, hutang, dan modal dari suatu perusahaan pada tanggal tertentu, sedangkan perhitungan rugi laba memperlihatkan hasil-hasil yang telah dicapai oleh perusahaan serta biaya yang terjadi selama periode tertentu, dan laporan perubahan modal menunjukkan sumber dan penggunaan atau alasan-alasan yang menyebabkan perubahan modal.

Tujuan keseluruhan dari laporan keuangan menurut Hery (2016) adalah untuk memberikan informasi yang berguna bagi investor dan kreditor dalam pengambilan keputusan investasi dan kredit. Tujuan khusus laporan keuangan adalah menyajikan posisi keuangan, hasil usaha dan perubahan posisi keuangan lainnya secara wajar dan sesuai dengan prinsip-prinsip akuntansi yang berlaku umum.

Ada berbagai langkah yang harus ditempuh dalam menganalisis laporan keuangan menurut Prastowo dan Rifka dalam Vitantya (2010:13) dapat dijabarkan sebagai berikut, yaitu:

- Memahami latar belakang data keuangan perusahaan

Pemahaman latar belakang data keuangan perusahaan yang dianalisis mencakup pemahaman tentang bidang usaha yang diterjuni oleh perusahaan dan kebijakan akuntansi yang dianut dan diterapkan oleh perusahaan tersebut. Memahami latar belakang data keuangan perusahaan yang akan dianalisis merupakan langkah yang perlu dilakukan sebelum menganalisis laporan keuangan tersebut.

- Memahami kondisi-kondisi yang berpengaruh pada perusahaan

Selain latar belakang data keuangan, kondisi-kondisi yang mempunyai pengaruh terhadap perusahaan perlu juga untuk dipahami. Kondisi-kondisi yang perlu dipahami mencakup informasi mengenai trend (kecenderengan) industri dimana perusahaan beroperasi, perubahan teknologi, perubahan selera konsumen, perubahan faktor-faktor ekonomi seperti perubahan pendapatan per kapita, tingkat bunga, tingkat inflasi dan pajak, dan perubahan yang terjadi di dalam perusahaan itu sendiri, seperti perubahan manajemen kunci.

- Mempelajari dan mengkaji laporan keungan

Sebelum berbagai teknik analisis laporan keuangan diaplikasikan, perlu dilakukan pengkajian terhadap laporan keuangan secara menyeluruh. Tujuan langkah ini adalah untuk memastikan bahwa laporan keuangan telah cukup jelas menggambarkan data keuangan yang relevan dan sesuai dengan standar akuntansi yang berlaku.

- Menganalisis laporan keuangan

Setelah memahami profil perusahaan dan mengkaji laporan keuangan, maka dengan menggunakan berbagai metode dan teknik analisis yang ada dapat menganalisis laporan keuangan dan menginterpretasikan hasil analisis tersebut.

\section{Du Pont System}

Menurut Falani (2013), Du Pont System merupakan cara yang efektif dalam menganalisa laporan keuangan perusahaan dengan model mengerucut, dimana hasilnya akan didapatkan nilai ROE dari suatu perusahaan. Analisis Du Pont System ini bersifat menyeluruh karena mencakup tingkat efisiensi perusahaan dalam penggunaan aktivanya dan dapat mengukur tingkat keuntungan atas produk yang dihasilkan oleh perusahaan tersebut. Du Pont 
System adalah suatu sistem analisis yang dimaksudkan untuk menunjukkan hubungan antara return on investment, net profit margin, dan total asset turnover.

Cara perhitungan dengan menggabungkan kedua rasio ini pertama kali dikembangkan pada perusahaan Du Pont guna pengendalian intern perusahaan. Dengan menggunakan kedua rasio tersebut dapat dilihat pengaruhnya satu sama lain. Dengan demikian dapat diketahui bagaimana rasio-rasio tersebut saling mempengaruhi dalam mencapai return on investment.

Analisis Du Pont terbentuk dari sejumlah persamaan-persamaan berikut ini:

- Aktiva lancar $=$ Kas + Piutang + Persediaan + Surat Berharga

- Aktiva Operasi = Aktiva Tetap + Aktiva Lancar

- Perputaran Aktiva Operasi = Penjualan Bersih : Aktiva Operasi

- Laba Setelah Pajak $=$ Penjualan Bersih $-(\mathrm{HPP}+$ Biaya Operasi + Bunga + Pajak)

- Margin Laba Bersih = Laba Setelah Pajak : Penjualan Bersih

ROI $=$ Perputaran Aktiva Operasi $\times$ Margin Laba Bersih

Gambar dibawah ini menunjukkan saling pengaruh dari masing-masing rasio tersebut, yaitu:

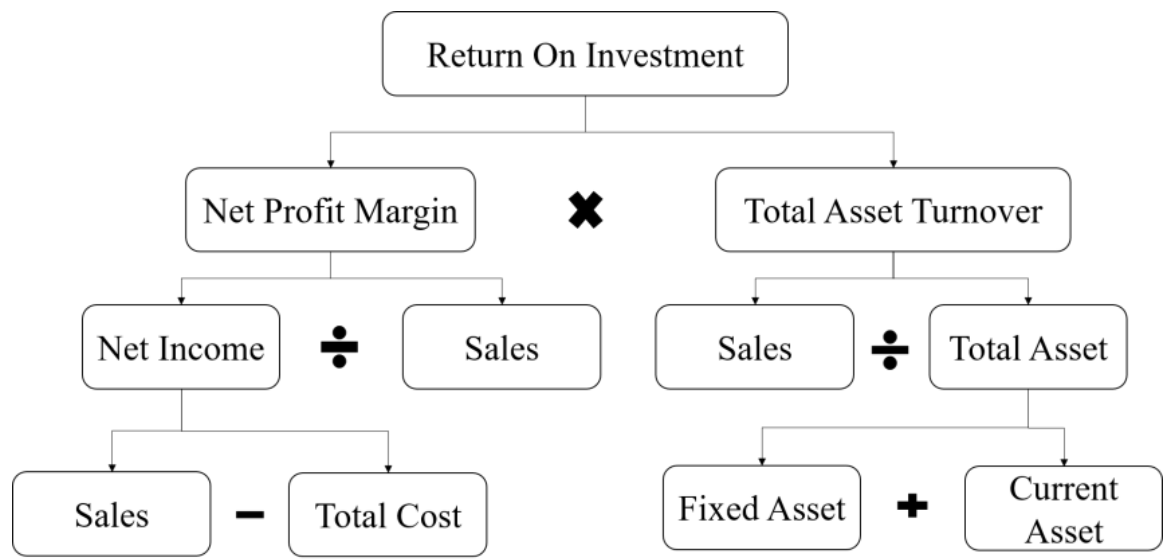

Sumber: Falani (2013)

Gambar 1. Du Pont System Model

Cara mengetahui sejauh mana tingkat keberhasilan manajemen PT Summarecon Agung TBK dan PT Pakuwon Jati TBK dalam mengelola perusahaan diuraikan dengan analisis $d u$ pont system untuk menilai kinerja keuangan perusahaan, dimana rasio keuangan yang ada diperusahaan nantinya diperbandingkan dengan rasio tahun-tahun yang lalu (time series). Perhitungan rasio dilakukan untuk menilai kinerja keuangan agar dapat memberikan informasi yang lebih akurat mengenai kinerja keuangan perusahaan sehingga dapat membantu manajemen dalam pengambilan keputusan yang lebih tepat.

Sistem $D u$ Pont sering digunakan untuk pengendalian divisi, prosesnya disebut dengan pengendalian terhadap tingkat pengembalian investasi (ROI). Jika ROI untuk divisi tertentu berada di bawah angka yang ditargetkan, melalui sistem $D u$ Pont dapat ditelusuri sebab-sebab terjadinya penurunan ROI.

\section{Analisis Economic Value Added (EVA)}

Dengan melihat era persaingan ketat di pasar global sekarang ini, tujuan perusahaan untuk memaksimalkan laba menjadi sulit tercapai. Tujuan utama perusahaan tentunya adalah untuk meningkatkan nilai tambah ekonomis. DR. Agus Zainul (perkuliahan Manajemen Keuangan Universitas Tarumanagara, November 11, 2017) mengatakan bahwa tujuan suatu perusahaan selain untuk mencari laba ialah untuk mensejahterakan para pemegang saham.

Suatu perusahaan yang mendapatkan laba besar belum tentu para pemegang sahamnya sejahtera, karena bisa saja perusahaan tersebut tidak membayar dividen. Oleh 
sebab itu diperlukan suatu pengukuran untuk melihat tingkat kesejahteraan tersebut dan biasa kita kenal dengan analisis Economic Value Added (EVA).

Economic Value Added (EVA) didefinisikan sebagai "perbedaan antara laba operasi setelah pajak dengan biaya modalnya", (Warsono dalam Nirmala et al., 2016). EVA memfokuskan pada efektivitas manajerial dalam suatu tahun tertentu.

Economic Value Added (EVA) adalah nilai tambah kepada pemegang saham oleh manajemen dalam suatu periode tertentu. EVA merupakan suatu estimasi laba ekonomis yang sesungguhnya dari perusahaan dalam tahun berjalan. EVA menunjukkan sisi laba setelah biaya modal, termasuk modal ekuitas, dikurangkan sedangkan laba akuntansi ditentukan tanpa memperhitungkan modal ekuitas (Brighem and Houston dalam Vitantya, 2010:51)

Dari uraian singkat di atas, dapat disimpulkan bahwa pengertian EVA adalah suatu konsep yang digunakan untuk mengukur kinerja keuangan yang menghitung nilai tambah yang dihasilkan perusahaan kepada investor, model ini dirumuskan dengan mengurangi keseluruhan biaya modal (cost of capital) yang timbul sebagai akibat dari investasi yang dilakukan. Prinsip EVA memberikan sistem pengukuran yang baik untuk menilai suatu kinerja dan prestasi keuangan manajemen perusahaan karena EVA berhubungan langsung dengan nilai pasar sebuah perusahaan.

berikut:

Untuk menghitung EVA digunakan rumus, langkah-langkahnya ialah sebagai

- Menghitung biaya hutang tahunan (Cost of Debt/K $\left.\mathrm{K}_{\mathrm{d}}\right)$

- Menghitung biaya ekuitas atau modal sendiri (Cost of Equity/ $\mathrm{K}_{\mathrm{e}}$ )

- Menganalisis struktur modal

- Menghitung modal rata-rata tertimbang

- Menghitung Ecomonic Value Added (EVA)

Widayanto (sebagaimana dikutip dalam Arindia et al, 2012), menjelaskan bahwa penilaian atas EVA dapat dinyatakan sebagai berikut:

- EVA >0,

Ini dapat diartikan pihak manajemen mampu menghasilkan nilai tambah bagi perusahaan melalui kegiatan operasionalnya sehingga bukan hanya mampu membayar seluruh kewajibannya kepada penyandang dana dan pemerintah melainkan juga mampu menyisakan laba bagi perusahaan. Atau dengan kata lain perusahaan yang memiliki EVA positif adalah perusahaan sehat.

- $\quad$ Jika EVA = 0

Maka secara ekonomis perusahaan dalam keadaan impas karena semua laba yang tersedia digunakan untuk membayar kewajiban kepada penyedia dana baik kreditur maupun pemegang saham.

- $\quad$ EVA $<0$,

Ini dapat diartikan pihak manajemen tidak mampu menghasilkan nilai tambah bagi perusahaan karena laba yang dihasilkan tidak mencukupi kebutuhan untuk membayar seluruh kewajiban kepada penyandang dana dan pemerintah.

\section{METODOLOGI PENELITIAN}

\section{Jenis dan periode penelitian}

Jenis penelitian yang digunakan adalah penelitian deskriptif, yang mana penulis mengumpulkan laporan keuangan PT Summarecon Agung Tbk dan PT Pakuwon Jati Tbk, yang kemudian menjelaskan hasil dari analisis Du Pont System dan analisis Economic Value Added (EVA) dengan membandingkan kedua perusahaan tersebut.

Periode penelitian yang digunakan dalam pengukuran kinerja PT Summarecon Agung Tbk dan PT Pakuwon Jati Tbk diambil dari laporan keuangan kedua perusahaan 
tersebut untuk periode 2015-2017 yang mana diharapkan dapat mewakili kondisi yang perusahaan sedang hadapi.

\section{Sumber dan Pengumpulan Data}

Sumber data yang digunakan dalam penelitian ini menurut cara memperolehnya adalah data sekunder, yaitu data yang diperoleh secara tidak langsung melalui media perantara. Sumber data sekunder tersebut yaitu:

- Data mengenai laporan keuangan perusahaan periode 2015 sampai dengan 2017 yang dapat diakses secara online melalui http://www.idx.co.id

- Data mengenai informasi dan operasional kedua perusahaan menggunakan data dari website resmi PT Summarecon Agung Tbk (http://www.summarecon.com) dan PT Pakuwon Jati Tbk (http://www.pakuwon.com).

- Data mengenai tingkat suku bunga SBI periode 2015-2017

- Data mengenai Indeks Harga Saham Gabungan (IHSG) periode 2015-2017,

- Data mengenai harga saham masing-masing perusahaan periode 1 Januari - 31 Desember 2017.

Teknik pengumpulan data yang digunakan dalam tesis ini adalah riset kepustakaan. Riset kepustakaan dilakukan dengan membaca dan mempelajari buku, literatur, dan tulisantulisan lainnya yang berhubungan dengan topik tesis ini. Riset kepustakaan dimaksudkan untuk mendapatkan landasan teori yang relevan dalam menyusun tesis nantinya, seperti sebagaumana teknik-teknik untuk melakukan analisis laporan keuangan.

\section{Teknik Analisis Data}

Teknik analisis data pada penelitian ini ialah nantinya keseluruhan data yang terkumpul selanjutnya dianalisis untuk dapat memberikan jawaban yang tepat. Langkahlangkah yang dilakukan pada analisa ini, meliputi :

- Menghitung rasio-rasio perusahaan sesuai dengan variabel yang ada pada metode analisis Du Pont untuk mengukur faktor-faktor yang mempengaruhi tingkat return on investment (ROI), diantaranya:

$>$ Menghitung net profit margin

$>$ Menghitung total asset turnover

$>$ Menghitung return on investment (ROI)

- Melakukan perhitungan Economic Value Added (EVA) untuk dapat terlihat kinerja perusahaan diukur dari nilai tambah yang dihasilkan, diantaranya dengan:

$>$ Menghitung biaya hutang tahunan (Cosi of Debt/K $\mathrm{K}_{\mathrm{d}}$ )

$>$ Menghitung biaya ekuitas atau modal sendiri (Cost of Equity/ $\mathrm{K}_{\mathrm{e}}$ )

$>$ Menganalisis struktur modal

$>$ Menghitung modal rata-rata tertimbang (Weighted Average Cost of Capital/WACC)

- Membandingkan hasil dari data yang sudah diolah sesuai dengan penerapan metode analisis Du Pont System dan Economic Value Added (EVA) pada kedua perusahaan yang menjadi sampel penelitian untuk periode 2015-2017.

- Menarik kesimpulan mengenai apa yang menjadi prediksi kondisi keuangan PT Summarecon Agung Tbk dan PT Pakuwon Jati Tbk periode 2015-2017.

\section{HASIL DAN KESIMPULAN}

Ditinjau dari segi analisis dengan metode $d u$ pont system menunjukkan bahwa pada tahun 2015-2017, tingkat pengembalian atau Return on Equity (ROE) yang berhasil dilakukan oleh PT Summarecon Agung Tbk ialah mengalami penurunan setiap tahunnya, sedangkan PT Pakuwon Jati Tbk mengalami peningkatan sekaligus penurunan yang tidak 
terlalu signifikan. Sebagaimana diketahui, ROE merupakan besarnya tingkat pengembalian yang dilakukan perusahaan dalam memberikan imbalan atas hasil yang diperoleh oleh peruashaan setiap tahunnya kepada para investor atas investasi yang dilakukan kepada perusahaan.

Di tahun 2015, tingkat pengembalian atas investasi PT Summarecon Agung Tbk ialah sebesar 14,13\%. Di tahun 2016, tingkat pengembalian investasi PT Summarecon Agung Tbk mengalami penurunan yaitu dari $14,13 \%$ menjadi $7,41 \%$. Begitu juga terjadi di tahun 2017, penurunan dari 7,41\% menjadi 6,37\% untuk PT Summarecon Agung Tbk. Untuk PT Pakuwon Jati Tbk, tingkat pengembalian atas investasi ialah sebesar 14,81\% di tahun 2015. Kemudian terjadi peningkatan pengembalian atas investasi PT Pakuwon Jati Tbk di tahun 2016 yaitu menjadi 16,16\%. Di tahun 2017, terjadi penurunan yang tidak signifikan yaitu sebesar $15,83 \%$. Dalam hal tingkat pengembalian yang berhasil dihasilkan oleh perusahaan, PT Pakuwon Jati Tbk lebih memberi tingkat pengembalian dibandingkan dengan PT Summarecon Agung Tbk.

Penilaian kinerja keuangan yang dilakukan dengan analisis Economic Value Added (EVA) dilakukan guna mengerahui bagaimana kinerja keuangan perusahaan dalam hal menciptakan nilai ekonomi ke dalam perusahaan atau untuk mengetahui ada atau tidaknya penciptaan nilai dari sebuah investasi yang dilakukan. Sesuai dengan analisis yang dipaparkan, pada tahun 2015-2017 PT Summarecon Agung Tbk dan PT Pakuwon Jati Tbk menghasilkan kinerja yang sama namu dengan nilai yang berbeda. Pada tahun 2015-2017 tersebut, baik PT Summarecon Agung Tbk maupun PT Pakuwon Jati Tbk, keduanya memberikan nilai EVA yang positif sehingga dapat disimpulkan bahwa dalam menjalankan kegiatan operasionalnya, perusahaan mampu menciptakan nilai ekonomi kepada perusahaan sehingga dapat dikatakan bahwa kinerja perusahaan tersebut dalam keadaan baik serta para investor mendapatkan imbalan uang sesuai dengan harapan atas investasi pada masingmasing perusahaan tersebut.

\section{DAFTAR PUSTAKA}

Falani, Z. Achmad. (2013). Analisis Laporan Keuangan Perusahaan Sebagai Dasar Pengambilan Keputusan Investasi Saham Berbasis Du Pont System \& Fuzzy Logic. Surabaya : ISSN 1858-4667 Jurnal Link Vol 18/No.1/Maret 2013, Universitas Narotama.

Hery. (2016). Mengenal dan Memahami Dasar-dasar Laporan Keuangan. Jakarta : PT Grasindo

Novianingtyas, Riska. (2013). Pengaruh DER, EPS, Resiko Sistematis, dan Kebijakan Dividen terhadap Harga Saham Perusahaan yang Terdaftar di BEI (Studi pada Perusahaan yang Masuk dalam Indeks LQ45 di Bursa Efek Indonesia periode 20102012). Surabaya: Universitas Brawijaya.

Rachbini, Didick J. (1997). Pembangunan Ekonomi Nasional: Suatu Pendekatan Pemerataan, Keadilan dan Ekonomi Kerakyatan. Jakarta: PT. Intermasa

Sutardi. (2007). Penggunaan analisis rasio keuangan, analisis Du Pont dan Metode EVA untuk menilai kinerja keuangan PT Mayora Indah Tbk. Jakarta : Pascasarjana Universitas Tarumanagara.

Vitantya, Robertus DA. (2010). Analisis Kinerja Keuangan Dengan Metode Analisis Du Pont dan Metode Analisis Economic Value Added (EVA), Studi Kasus PT Astra Internasional Tbk Tahun 2004-2008. Yogyakarta : Fakultas Ekonomi Prodi Manajemen Universitas Sanata Dharma.

http://www.bi.go.id

https://finance.yahoo.com

https://idx.co.id 
https://www.merdeka.com/uang/hidayat-properti-jadi-penyelamat-pertumbuhan-sektorindustri.htmlhttps://pakuwon.com

https://pakuwon.com

https://www.sahamgain.com/2016/09/analisis-fundamental-saham-return-to.html

https://summarecon.com 
